\title{
The Path to Inclusive Growth in Nigeria: Are People with Disabilities Carried Along?
}

\author{
Emmanuel O. Okon ${ }^{1}$ \\ ${ }^{1}$ Department of Economics, Kogi State University, Anyigba, Kogi State, Nigeria \\ Correspondence: Department of Economics, Kogi State University, Anyigba, Kogi State, Nigeria, E-mail: \\ tonydom57@yahoo.com. Tel: +2348023275716
}

Received: January 2, $2018 \quad$ Accepted: January 4, $2018 \quad$ Online Published: January 9, 2018

\begin{abstract}
The growing disconnect between the improving macro-economic indicators and the growing descent into poverty of over 170 million Nigerians is clearly anindicative of the fact that economic growth in Nigeria is non-inclusive as the country may have only attained what is known as growth without development. Using a purely descriptive and analytical methodology, this paper shows that inclusive growth is the growth that generates employment opportunities and reduces the depth and severity of the incidence of poverty. However, people with disability have in many cases been denied of job opportunities in Nigeria. This paper argues that the country cannot have inclusive growth unless disability is made an integral part of her growth. Considering that the economic inclusion of people with disabilities is a cross-cutting issue, successful results require complementary activities in multiple sectors. However, inclusion of people with disabilities in work/employment can lead to greater economic self-sufficiency. Though it should not be promoted as the only option for economic inclusion, self-employment can be a good alternative, especially in a country like Nigeria where there is a general dearth of opportunities for formal sector jobs. In that regard, this paper suggests that microfinance institutions should extend credit and other financial services for self-employment of people with disabilities. Better still, specialized microfinance should be established for people with disabilities to provide supporting or complementary services.
\end{abstract}

Keywords: Poverty, Disabilities, People with Disabilities, Inclusive Growth, Nigeria.

\section{Introduction}

Located in the continent of Africa on the west coast, Nigeria covers 910,768 square kilometers of land and 13,000 square kilometers of water, making it the 32nd largest nation in the world with a total area of 923,768 square kilometers (Worldatlas.com, 2016). It lies on latitudes $4^{\circ}$ north of the Equator and latitudes $3^{\circ}$ and $14^{\circ}$ on the east of the Greenwich Meridian. Shares boundaries with The Republics of Benin and Niger in the west, Cameroon in the East, Niger and Chad in the north and the Gulf of Guinea in the South (NNPCgroup.com, n.d.).

The country's economic aspirations have remained that of altering the structure of production and consumption patterns, diversifying the economic base and reducing dependence on oil, with the aim of putting the economy on a part of sustainable, all-inclusive and non-inflationary growth. The implication of this is that while rapid growth in output, as measured by the real gross domestic product (GDP), is important, the transformation of the various sectors of the economy is even more critical. This is consistent with the growth aspirations of most developing countries, as the structure of the economy is expected to change as growth progresses. Successive governments in Nigeria have since independence in 1960, pursued the goal of structural changes without much success. The growth dynamics have been propelled by the existence and exploitation of natural resources and primary products. Initially, the agricultural sector, driven by the demand for food and cash crops production was at the centre of the growth process, contributing 54.7 per cent to the GDP during the 1960s (Kelikume, 2015). The second decade of independence saw the emergence of the oil industry as the main driver of growth. Since then, the economy has mainly gyrated with the boom-burst cycles of the oil industry. Government expenditure outlays that are dependent on oil revenues have more or less dictated the pace of growth of the economy. Looking back, it is clear 
that the economy has not actually performed to its full potential, particularly in the face of its rising population. The Nigerian economy has grossly underperformed relative to her enormous resource endowment and her peer nations. It has the 6th largest gas reserves and the 8th largest crude oil reserves in the world. It is endowed in commercial quantities with about 37 solid mineral types and has a population of over 170 million people. Yet economic performance has been rather weak and does not reflect these endowments. Compared with the emerging Asian countries, notably, Thailand, Malaysia , China, India and Indonesia that were far behind Nigeria in terms of GDP per capita in 1970, these countries have transformed their economies and are not only miles ahead of Nigeria, but are also major players on the global economic arena.

The major factors accounting for the relative decline of the country's economic fortunes are easily identifiable as political instability, lack of focused and visionary leadership, economic mismanagement and corruption. Prolonged period of military rule stifled economic and social progress, particularly in the three decades of 1970s to 1990s. During these years, resources were plundered, social values were debased, and unemployment rose astronomically with concomitant increase in crime rate.

However, since 1999 economic growth in Nigeria has risen substantially, with annual average of 7.4 per cent in the last decade (Kelikume, 2015) (see Table 1 in appendix for economic indicator for Nigeria in 20015). But the growth has not been inclusive, broad-based and transformational. The implication of this trend is that economic growth in Nigeria has not resulted in the desired structural changes that would make manufacturing the engine of growth, create employment, promote technological development and induce poverty alleviation. Available data has put the national poverty level at 54.4 per cent (Kelikume, 2015). Similarly, there has been rising unemployment with the current level put at 19.7 per cent by the National Bureau of Statistics (NBS) (Kelikume, 2015).

The United Nations estimates that 10-12 per cent of the world's population, over 600 million people, has some form of disability (World Bank (2006). Of this total, 80 per cent live in low-income countries (WHO (2005). About 82 per cent of them live below the poverty line (Handicap International and Blindenmission, 2006). It is estimated that 80 per cent of all people with disabilities of working age are unemployed (Harris, 1997).

According to 2006 National Population Census, there are more than 19million persons with disabilities in Nigeria - a population equal to that of a megacity like Lagos State (Adeyanju, 2009). Disability is both a cause and a consequence of poverty. There is a strong relationship between disability and poverty with a cyclical tendency poverty makes people more vulnerable to disability and disability reinforces and deepens poverty. Disability is an important factor, along with gender, race and caste, that interacts to impoverish people and keep them poor (Mji et al, 2009). People with disability are often excluded from the mainstream of society, and hence, may not contribute to the development of the society at all or optimally. The World Bank considers that leaving people with disabilities outside the economy translates into a forgone GDP of about 5-7 per cent (DFID, 2000).It is increasingly being recognized that bringing people with disabilities into the development mainstream will have a significant effect in any plan to cut poverty in the developing world (Wolfensohn, 2003).

Against this background, this paper aims at examining the conditions of people with disability with a view to proposing measures for delivering inclusive growth to achieve economic development. This paper has been divided into five sections. Section 1 is the introductory section and contains the objective of the paper. Section 2 presents conceptual issues and literature review. Section 3 is devoted to the discussion of the global prevalence of disability; people with disabilities in Nigeria; situation of PWD in Nigeria; economic inclusion of people with disability in the scheme of growth in Nigeria- employment perspectives. Section 4 presents the way forward for Nigeria. The conclusion is presented in section 5 .

2. Concept of Inclusive Growth

According to Microsoft Encarta (2009) the word "inclusive" refers to including many things or everything, people of all kind, non-discriminatory. It is synonymous to comprehensive, wide-ranging, all encompassing, complete and broad. "Growth" refers to the process of becoming larger and more mature, increase in number, size, power or intensity. It is synonymous to development, growing, evolution, progress, advance, progression, enlargement, increase, expansion, augmentation, intensification and escalation.

From the above inclusive growth can be taken to mean: the process of becoming larger and more mature including many things or everything and non-discriminatory. It can mean increase in number, size, power or intensity that includes people of all kind within a community, society, local government, state or a country (Adamu,2017).

The meaning of inclusive growth can further be juxtapose to refer to the following: comprehensive development, wide-range development, all-encompassing development, complete development, broad development, comprehensive growth, wide-range growth, all-encompassing growth, complete growth, broad growth, comprehensive evolution, wide range evolution, all-encompassing evolution, complete evolution, broad evolution, comprehensive progress, wide range progress, all-encompassing progress, complete progress, broad progress, 
comprehensive advancement, wide range advancement, all-encompassing advancement, complete advancement, broad advancement, comprehensive progression, wide range progression, all-encompassing progression, complete progression, broad progression, comprehensive enlargement, wide range enlargement, all-encompassing enlargement, complete enlargement, broad enlargement, comprehensive increase, wide range increase, allencompassing increase, complete increase, broad increase, comprehensive expansion, wide range expansion, allencompassing expansion, complete expansion, broad expansion, comprehensive augmentation, wide range augmentation, all-encompassing augmentation, complete augmentation, broad augmentation, comprehensive intensification, wide range intensification, all-encompassing intensification, complete intensification, broad intensification, comprehensive escalation, wide range escalation, all-encompassing escalation, complete escalation and broad escalation. The list is endless and interesting, the more we go into it the broader the understanding (Adamu,2017).

According to Wikipedia (2016) "Inclusive growth" basically means making sure everyone is included in growth regardless of their economic class, gender, sex, disability and religion. "Inclusive growth refers to the pace and pattern of growth which is considered, interlinked that need to be address together. It is about raising the pace of growth and enlarging the size of the economy, while leveling the playing field for investment and increasing productive employment opportunities" (Lanchovichina and Lundstrom, 2009). It is depicted as output growth that is sustained over decades, is broad-based across economic sectors, creates productive employment opportunities for a great majority of the country's working age population, and reduces poverty (World Economic Forum, 2015). The European commission (2012) described inclusive growth as "a high employment economy delivering economic, social and territorial. It means raising employment rate more and better jobs especially for women, young people and older workers helping people of all ages anticipate and manage change through investment in skill and training modernizing labour markets and welfare systems ensuring the benefits of growth reach all parts of the society".

Inclusive Growth is about expanding national economy and ensuring that most vulnerable people of societies are reached- the "equality of opportunity" and "participation in growth by all" are the basis of inclusive growth (UNDP, 2015). It is economic growth that creates opportunities for all segments of the population and distributes the dividends of increased prosperity, both in monetary and non-monetary terms, fairly across society (OECD, 2014).

However, favorable factors for promoting Inclusive Growth are categorized into macro and micro factors. The macro factors among others include better financial regulation, openness to foreign direct investment, trade liberalization, providing social safety, reorientation of public expenses, lawful and political reforms. The micro factors among others include: reducing income and non-income associated unfairness, developing infrastructure, empowerment, access to market, roles played by civil society organizations, accountability and good governance (UKEssays 2015).

2.1. Review of Literature

2.1.1. Inclusive Growth

Inclusive growth is now well accepted as the key economic goal for developing countries. It generally includes but extends pro-poor growth. The assumption is that growth which is beneficial for the large majority of people in developing countries is more likely to be economically and politically sustainable. McKay. (2008) stresses the importance of promoting broad-based growth, which it argues is more likely to result in sustained growth. It outlines some of the barriers that the poor face in participating in growth opportunities. According to him, economic insecurity and high levels of vulnerability mean that the poor are less likely to engage in risk-taking activities, which have the potential to be more profitable. Furthermore, many of the poor live in more remote areas or are members of long-term disadvantaged groups - and thus tend to be less well served by public policies and have less access to growth opportunities. The paper concludes that a lower level of assets, including human capital, limits the scope of participation by the poor in growth.

Ali (2007) highlights the problem of rising income and non-income inequalities in Asia and the need for inclusive growth in order to mitigate the rise in inequality. Income inequality stems in part from higher demand and thus higher wages for skilled workers, due to the rising importance of new technologies and foreign direct investment. In addition, non-income inequalities have risen with the decline in effective delivery of public services. The paper outlines that promoting inclusive growth requires creation of opportunities, including addressing economic, social and political constraints in generating opportunities; equalizing access to opportunities generated by growth by addressing the disadvantages of circumstances (e.g., strengthening human capabilities to enable individuals to qualify for productive and decent employment); and providing social protection schemes in order to reach the chronically poor who may still be unable to access such opportunities and participate in growth. The paper also stresses the importance of measuring inclusive growth and the extent and degree to which inclusiveness is attained. This has received less attention than policy formulation. Measurement should focus on average opportunities and 
distribution of opportunities; and can be carried out for individual components, e.g., employment, access to education, access to health facilities, etc. Mendoza and Thelen (2008) stresses that facilitating access of the poor to markets ('market access'), however, does not necessarily result in successful engagement with markets and the attainment of positive development impacts ('inclusive markets'). These authors' outlines the barriers that poor people face in accessing and participating in markets as producers and consumers; and remedies provided by private sector actors. As producers, poor people can be excluded from access to labour and various product markets due to: lack of access to credit; limited investment in their human capital (including skills and entrepreneurship training); and geographic obstacles, such as their location in rural areas. Markets can promote economic growth and can provide a range of benefits to those able to access and participate successfully in them. The ability to engage with markets, however, varies across groups(Ogujiuba and Alehile, 2011).

Speaking of groups, the studies reviewed were not specific about the nature of the poor concerned; however, this paper is concerned about the poorest of the poor (i.e., people with disabilities). It is estimated that 10-12per cent of the world's population has some kind of disability and that 82per cent of people with disabilities live below the poverty line(Handicap International, 2006).

2.1.2. The Economic Benefits of Adopting a Disability Inclusive Approach to Development: Empirical Studies

The economic benefits of adopting a disability inclusive approach to development are complex and difficult to quantify as a result of a lack of data (Walton, 2012). One study in Nepal finds that wage returns to education for people with disabilities are very high, ranging from 19.3 to 25.6 per cent (Lamicchane and Sawadea, 2009; Lamicchane, 2015). However, 'at least 10 years of schooling are necessary for returns on the investment in education to turn positive' (Lamicchane, 2015). Further work in Nepal, the Philippines, and Cambodia, found that 'people with disabilities who enjoy longer years of schooling tend to be engaged in full-time or white-collar jobs which are usually associated with greater income stability' (Lamicchane, 2015). In addition, a study across 13 low and middle-income countries found that 'each additional year of schooling completed by an adult with a disability reduced the probability by $2-5$ per cent that his/her household belonged to the poorest two quintiles' (Morgon Banks and Polack, 2014). It is estimated that in Pakistan, 'rehabilitating people with incurable blindness would lead to gross aggregate gains in household earnings of USD 71.8 million per year' (Morgon Banks and Polack, 2014).

The inclusion of people with disabilities in work/employment can lead to greater economic self-sufficiency, which decreases demands on social assistance; although evidence from low- and middle-income counties is lacking (Morgon Banks and Polack, 2014). Evidence from high-income countries also indicates that 'with the proper job matching and the right accommodations, employees with disabilities can be just as productive as other workers and their inclusion may even increase overall profit margins' (Morgon Banks and Polack, 2014).

It is anticipated that increasing labour force participation of both people with disabilities and their caregivers will increase a country's potential tax base (Morgon Banks and Polack, 2014). In the Philippines, for example, excess unemployment among individuals with unrepaired cleft lips and palates cost the government between USD 8-9.8 million dollars in lost tax revenue (Morgon Banks and Polack, 2014). More evidence is available from highincome countries. In Scotland, evidence indicates that every $£ 1$ spent on a supported employment project led to a savings of $£ 5.87$, due in large part to decreased need for disability/welfare benefits and increased tax income (Morgon Banks and Polack, 2014).

A study of disability and equity at work finds that 'work provides the material means through which to acquire adequate food, clothing, and shelter; access education, health care, and support services; and participate in the cultural, recreational, and social life of one's community' (Heymann et al., 2014). Including people with disabilities in the labour market also reduces stigma and promotes inclusion (Heymann et al., 2014). Gainful employment can have a significant positive impact on feelings of worth, ability, and self-determination for individuals with disabilities, as well as increasing their social and civic interaction (Morgon Banks and Polack, 2014; Heymann et al., 2014; Lamicchane, 2015; Burns and Oswald, 2014).

A quasi-randomized control trial in India found that community-based rehabilitation (CBR) programmes significantly improved the well-being and access to services of people with disabilities (Mauro et al., 2014). Compared to the control group, access to pensions and allowances, aid appliances, access to paid jobs and personalpractical autonomy for the people with disabilities involved in the CBR programmes increased by 29.7 per cent, 9.4 per cent, 12.3 per cent and 36.2 per cent respectively after seven years (Mauro et al., 2014).

A randomized control trial in China found that people with schizophrenia who received individualized family-based interventions worked 2.6 months more per year than those who did not receive the treatment (Morgon Banks and Polack, 2014). A study in Bangladesh found that 'children who were provided with assistive devices (hearing aids or wheelchairs) were more likely to have completed primary school compared to those who did not receive any 
supports' (Morgon Banks and Polack, 2014). A small study in Ethiopia found that the provision of wheelchairs led to a 'significant time reallocation away from begging (1.40 fewer hours per day) and toward income-generating activity (1.75 more hours per day) and 77.5 per cent higher income' (Grider and Wydick, 2015).

Little evidence is available, but recent research on disability inclusion in gender-based violence activities in refugee camps found that including women and girls with disabilities, and their caregivers, fostered relationship building and trust among women and girls with disabilities, as well as with others in the community (WRC, 2015). Inclusion also led to information exchange, skills building, and improved self-esteem. It enabled women and girls with disabilities to be recognized, not for their impairment, but for their roles as leaders, friends and neighbors, making positive contributions to their communities (WRC, 2015). Women with disabilities and caregivers in the VSLAs also reported 'increased independence and decision-making and greater respect and status within the family and community as a result of their newfound access to income-earning opportunities' (WRC, 2015).

\subsection{Concept of Disability}

In simple terms, disability is the limitation in performing certain tasks that society expects of an individual. Disability permeates every society, and has done so through the ages (Lambo, 1981; World Report on Disability, 2011). Today, in most parts of the world, the disabled include persons with intellectual, developmental, sensory, physical or other dysfunctions, which may be acquired, congenital, or even hereditary (Dell Orto and Power, 2007). In the absence of effective education or rehabilitation, such disabilities have the potential to impede a person's full participation in the society and the performance of social roles.

\subsection{Models of Disability}

Models of Disability are tools for defining the concept of impairment and they provide a basis upon which governments at all levels can devise strategies for meeting the needs of PWDs in the society. There are several models which can be used to define and empower people with disabilities, giving them full and equal rights alongside their fellow citizens. Among these models are the Medical Model, which results from an individual person's physical or mental limitations; Tragedy/Charity Model, which depicts Persons with Disabilities as victims of circumstances, deserving pity; the Social Model, which views disability as a consequence of environmental, social and attitudinal barriers that prevent people with impairments from maximum participation in societal activitie s. The human rights model, derived from the social model, is based on the principle that all people must access equal opportunities to participate in society. This model's main goal is to empower people with disabilities and to guarantee their right to equal and active participation in political, economic, social, and cultural activities (Handicap International, 2006).

Others are the Social Adaptive Model, which recognizes that the inability of PWDs to adapt to the demands of society may be a contributory factor to their conditions; the Economic Model, which sees disability as the person's inability to participate in work, assessing the degree to which impairment affects an individual's productivity; the Customer/Empowering Model, which enables the client decide and select what services he/she believes are appropriate; and the Religious Model, which views disability as a punishment inflicted upon an individual or family by an external force(FMWASD, 2011). The Disability Creation Process Model considers disability not as a fixed 'state' but as a process which limits a person's social and everyday activities (Fougeyrollas, 1999). Under this model, disability is considered a disturbance in a person's life habits (his or her full social participation) as a result of an interaction between the person's abilities and the person's environment. Disability is therefore a relative situation which varies from person to person and according to the context and the environment. This 'disability situation' can change or evolve by reducing the impairment, developing

3. Global Prevalence of Disability

The 2011 World Report on Disability (WHO/WB) uses two approaches to measuring disability namely the 2004 Global Burden of Disease and the 2004 World Health Surveys (WHS). In 2004, the Global Burden of Disease estimated that the prevalence of disability was at $19.4 \%$ of the global population while the World Health Survey estimates give a prevalence of $15.6 \%$. Using these proportions, it is estimated that between 785 million and 975 million people in the world have disabilities. Eighty percent of the PWDs worldwide live in developing countries and $82 \%$ live below the poverty line (Hope, 2003). The World Bank estimates that individuals with disabilities now comprise about $20 \%$ of the poorest of the poor (Elwan, 1999).

The prevalence of disability, as reported in the 2011 World Report on Disability, is consistent with prevalence reported in earlier studies in high income countries where prevalence has been over $10 \%$ and some even approaching $20 \%$. It is evident that over the last two decades African countries have continued reporting significantly lower rates compared to high income countries at around 5\% or less. Loeb and Eide (2004) suggest that there might be under-reporting of disability in low income countries. These differences might also be due to differences in the definitions of disability and assessment tools. 


\subsection{People with Disabilities in Nigeria}

The geographical distribution of persons with disabilities in Nigeria by states and geo-political according to the 2009-2010 National Baseline Survey is presented in Table 1 below. The national prevalence rate of PWDs was 3.2 per cent (FMWASD, 2011).Given an estimated national population of 150 million people, this finding suggests that 4.8 million Nigerians were living as PWDs(FMWASD,2011). A breakdown, by State, shows a marked variation in the prevalence. This estimate is scientifically a correct estimate of the population of PWDs in Nigeria within the context of theSurvey. However, the World Health Organization estimates of the population of PWDs in Nigeria to be about 19 million.

Report from the National Baseline Survey indicates by types of disability that the commonest type of disability was physical handicap (27.5\%), followed by blindness/visual disability (16.4\%), then by mental illness (13.3\%), then by autism (11.2\%), then by cerebral palsy (10.1\%), then by deafness/hearing disability (7.5\%), then by speech defect (5.2\%), and lastly other disabilities (1.1\%)(FMWASD, 2011). Gender-wise, females predominated in four of the specific categories, namely, physical handicap, blindness, cerebral palsy, and intellectual disability; whilst males predominated in the other four specific categories of mental illness, autism, deafness, and speech defect, as well as the omnibus category of the other disabilities. However, the magnitude of the size of predominance by females in relation to physical handicap and intellectual disability, in particular, has contributed to the overall dominance of the females over males in relation to the figures for gender-affiliated disabilities.

Also, data from the National Baseline Survey indicates that the majority of PWDs (52.6\%) do not have any form of education, across all the States. Those with First School Leaving Certificate and Modern School Leaving Certificate accounted for $17.3 \%$, and $1.1 \%$, respectively. Few (13.5\%) PWDs have SSS/"O" Level Certificate; while $0.4 \%$ and $6.5 \%$ of the PWDs, respectively, have vocational training and JSSCE, respectively. PWDs with "A" Level and NCE/OND accounted for $0.8 \%$ and 3.0\%, respectively. Further, $2.8 \%, 0.2 \%$ and $0.3 \%$ of the PWDs had attained the educational level of BA/BSc/HND, Technical/Professionals and Master's degree, respectively. Only $0.1 \%$ and $1.3 \%$ have doctorate degree and other qualifications, respectively (FMWASD,2011).

Table 1: National Disability Prevalence Rate, by State and by Geo Political Zone

\section{PWDs \% Non-PWDs \% Total \%}

\begin{tabular}{|c|c|c|c|c|c|c|}
\hline \multicolumn{6}{|l|}{ North Central } & 100.0 \\
\hline Kogi & 42 & 3.4 & 1,198 & 96.6 & 1,240 & 100.0 \\
\hline Kwara & 22 & 1.7 & 1,287 & 98.3 & 1,309 & 100.0 \\
\hline Nasarawa & 75 & 3.7 & 1,937 & 96.3 & 2,012 & 100.0 \\
\hline Niger & 9 & 4.0 & 216 & 96.0 & 225 & 100.0 \\
\hline Plateau & 25 & 1.4 & 1,722 & 98.6 & 1,747 & 100.0 \\
\hline FCT Abuja & 10 & 0.6 & 1,567 & 99.4 & 1,577 & 100.0 \\
\hline Total & 232 & 2.6 & 9,323 & 97.4 & 9,555 & 100.0 \\
\hline \multicolumn{7}{|l|}{ North East } \\
\hline Adamawa & 24 & 1.4 & 1,749 & 98.6 & 1,773 & 100.0 \\
\hline Bauchi & 52 & 2.6 & 1,966 & 97.4 & 2,018 & 100.0 \\
\hline Borno & 46 & 2.9 & 1,568 & 97.1 & 1,614 & 100.0 \\
\hline Gombe & 50 & 2.8 & 1,728 & 97.2 & 1,778 & 100.0 \\
\hline Taraba & 42 & 2.7 & 1,497 & 97.3 & 1,539 & 100.0 \\
\hline Yobe & 38 & 2.1 & 1,812 & 97.9 & 1,850 & 100.0 \\
\hline Total 252 & \multicolumn{2}{|c|}{2.4} & 10,320 & \multirow{2}{*}{\multicolumn{2}{|c|}{10,572}} & 100.0 \\
\hline North West & & & & & & \\
\hline Jigawa & 43 & 2.2 & 1,889 & 97.8 & 1,932 & 100.0 \\
\hline Kaduna & 48 & 2.7 & 1,758 & 97.3 & 1,806 & 100.0 \\
\hline Kano & 37 & 1.8 & 2,020 & 98.2 & 2,057 & 100.0 \\
\hline Katsina & 28 & 1.5 & 1,849 & 98.5 & 1,877 & 100.0 \\
\hline Kebbi & 51 & 2.5 & 1,950 & 97.5 & 2,001 & 100.0 \\
\hline
\end{tabular}




\begin{tabular}{|c|c|c|c|c|c|c|}
\hline Sokoto & 304 & 22.2 & 1,068 & 77.8 & 1,372 & 100.0 \\
\hline Zamfara & 33 & 1.9 & 1,716 & 98.1 & 1,749 & 100.0 \\
\hline Total 544 & \multicolumn{2}{|c|}{5.0} & 12,250 & \multirow[t]{2}{*}{95.0} & 12,794 & 100.0 \\
\hline South East & & & & & & \\
\hline Abia & 67 & 5.8 & 1,084 & 94.2 & 1,151 & 100.0 \\
\hline Anambra & 56 & 4.6 & 1,165 & 95.4 & 1,221 & 100.0 \\
\hline Ebonyi & 71 & 4.0 & 1,686 & 96.0 & 1,757 & 100.0 \\
\hline Enugu & 28 & 2.3 & 1,202 & 97.7 & 1,230 & 100.0 \\
\hline Imo & 86 & 6.0 & 1,340 & 94.0 & 1,426 & 100.0 \\
\hline Total & 308 & 4.5 & 6,477 & 95.5 & 6,785 & 100.0 \\
\hline \multicolumn{7}{|l|}{ South South } \\
\hline Akwa Ibom & 70 & 4.9 & 1,360 & 95.1 & 1,430 & 100.0 \\
\hline Bayelsa & 11 & 0.9 & 1,228 & 99.1 & 1,239 & 100.0 \\
\hline Cross River & 26 & 2.0 & 1,289 & 98.0 & 1,315 & 100.0 \\
\hline Delta & 81 & 7.1 & 1,053 & 92.9 & 1,134 & 100.0 \\
\hline Edo & 31 & 2.5 & 1,231 & 97.5 & 1,262 & 100.0 \\
\hline Rivers & 33 & 2.2 & 1,476 & 97.8 & 1,509 & 100.0 \\
\hline Total & 252 & 3.3 & 7,637 & 96.7 & 7,889 & 100.0 \\
\hline \multicolumn{7}{|l|}{ South West } \\
\hline Ekiti & 21 & 2.8 & 724 & 97.2 & 745 & 100.0 \\
\hline Lagos & 19 & 1.6 & 1,147 & 98.4 & 1,166 & 100.0 \\
\hline Ogun & 32 & 3.3 & 945 & 96.7 & 977 & 100.0 \\
\hline Ondo & 24 & 2.2 & 1,092 & 97.8 & 1,116 & 100.0 \\
\hline Osun & 16 & 1.6 & 962 & 98.4 & 978 & 100.0 \\
\hline Oyo & 12 & 1.0 & 1,224 & 99.0 & 1,236 & 100.0 \\
\hline Total & 124 & 2.1 & 6,094 & 97.9 & 6,218 & 100.0 \\
\hline TOTAL & 1,712 & 3.2 & 52,101 & 96.7 & 53,813 & 100.0 \\
\hline
\end{tabular}

Source: FMWASD(2011)

\subsection{Situation of PWD in Nigeria}

Nigerian Socio-Economic and Political Environment is suffocating PWDs (Adeyanju, 2009).Nigerian Environments consists of physical (mountains, air, water, ocean, rivers, lakes, rainfall, wind, temperature etc); biological (plants, animals, organisms); social (culture, tradition, towns, cities, institutions, governance systems, spirituality and religious systems etc); in a nutshell, the political, social and economic life of any country define the progress or backwardness of its citizenry. As such, the whole gamut of Nigerian environment as presently being experienced, is suffocating and retarding the growth of PWDs in the following ways: Political Environment: Since independence in 1960, persons with disabilities are still being excluded from participation in decision-making (at all levels). No seat is ever reserved for people with disabilities during elections and political parties continued in deceit and grandstanding as they do not deem it fit to "reserve" and post or seat in the parliament (at the three-tier government's level) or any posts in party hierarchy. Simply put, this exclusion for years (until now still going on) has aptly confined people with disabilities in Nigeria to the status of hewer-of-wood and drawer-of-water. They are living in servitude in their own fatherland! Their peers have gone on to consolidate, own big thriving businesses and are doing well with members of their families while majority of the people with disabilities continue to live on crumbs that fell from the table of their peers! Corruption, greed and avarice in Nigeria has denied them of good life as looting continues unabated, culminating in poor delivery of services viz: lack of education, decaying infrastructural facilities, poor healthcare delivery, lack of food for the swelling population in Nigeria majority of whom are so poor due to poverty and hordes of unemployed youths. Elections are blatantly rigged in Nigeria with godfathers dictating the tune (these godfathers would hardly be caught supporting or sponsoring a physically challenged), while thuggery, violence and mayhems are regular features during elections and also religious skirmishes all these resulting in swelling population of PWDs in Nigeria (Adeyanju, 2009).

Interestingly, the Federal Government of Alhaji Umaru Yar 'Adua constituted electoral reforms committee headed by the respected retired Justice Muhammad Uwais to see to it that Nigeria achieve free and fair elections in the future which means persons with disabilities may be ushered into participatory democracy soon( how happy they felt that 
an injustices of many decades is about to be corrected) but, the government continue to be sluggish while displaying lack of political will to implement the electoral reforms which should be the catalyst for changing the fortunes of persons with disabilities even till this present regime of Muhammad Buhari. Physical Environment: Roads and building constructed in Nigeria are not accessible to PWDs; roads are death traps, while we also have unfavorable weather conditions like heavy rainfall resulting in flooding, erosion, etc.The frequent gas flaring in the Niger Delta region produces heat waves. Similarly in the Northern Nigeria, the dry harmattan and humidity during the dry seasons often results in cerebral meningitis which is the major cause of deafness in this part of Nigeria. Destruction of ecosystems and faunas, constituting problem and we are well enjoying the hardships these brought as a result of increasing in disability population. Nigeria is a land with abundant God-given mineral resources name it; Oil, gold, marble, tin, coal and so on and so forth, but these resources have turned Nigeria into a cursed instead of a blessed country. Today, agitation for resource control is rampant because these resources are not being put into judicious use while a few cornered all the proceedings for themselves and their cronies causing poverty and disability. Socio-Economic Environment: Frankly speaking, persons with disabilities face stigmatization, deprivation, frustration, marginalization, exclusion, discrimination, segregation and negative attitude from the larger society. When it comes to securing job, many are jobless; when it is the turn of business opportunity, many lack the training, skills and education - a pre-requisite to setting up flourishing business; to access capital/funds for business development is like squeezing water from a rock as the banks will request for collaterals which many PWDs couldn't afford. Worse still, of the thousands of micro-finance houses that dotted the nooks and crannies of Nigerian nation, none is specifically designed to cater for persons with disabilities. There is nothing like social security whereby unemployed and the needy can receive certain amount as allowances. With businesses crumbling and some companies relocating to other countries due to high cost of productions and global economic meltdown, more persons with disabilities have been thrown into an already saturated job market, life is very difficult and unbearable for some and hence, proliferation of begging activities (Adeyanju, 2009).

To worsen the situation, the government of the day, in the name of beautification has destroyed houses and businesses of many poor people, some are now experiencing depression and if care is not taken, and mental disability will be on the increase.

These situations faced by people with disabilities in Nigeria are better summarized by Lang and Upah (2008) in Table 2 below.

Table 2: Barriers to the Social Inclusion of Disabled People in Nigeria

\begin{tabular}{|c|c|c|}
\hline Environmental & Institutional & Attitudinal \\
\hline $\begin{array}{l}\text {-Inaccessible public buildings } \\
\text {-Inaccessible transport system; } \\
\text { - Lack of access to computers \& the } \\
\text { internet } \\
\text {-Poor lighting } \\
\text { - Lack of accessible information, }\end{array}$ & $\begin{array}{l}\text { - Lack of disability legislation; } \\
\text {-Lack of robust and reliable } \\
\text { disability statistics } \\
\text { - No social protection; } \\
\text { - Inadequate provision of medical } \\
\text { and rehabilitation services; } \\
\text { - Lack of access to micro-finance } \\
\text { and banking services } \\
\text {-Inaccessibility to mainstream } \\
\text { public services, (especially } \\
\text { education) }\end{array}$ & $\begin{array}{l}\text {-The cause of impairment often } \\
\text { attributed to a "curse"; } \\
\text {-Disability issues are predominantly } \\
\text { perceived in terms of charity/welfare } \\
\text {-not in terms of human rights } \\
\text {-Lack of understanding of disability } \\
\text { issues by the general public }\end{array}$ \\
\hline
\end{tabular}

Source: Lang and Upah (2008)

\subsection{Economic Inclusion of People with Disability in the Scheme of Growth in Nigeria: Employment perspectives}

Considering that the economic inclusion of people with disabilities is a cross-cutting issue, successful results require complementary activities in multiple sectors. These may include health care, rehabilitation (including assistive devices), public education, barrier-free access, transport, communications, education, social welfare and community development, awareness on people with disabilities' rights, social security, sport and recreation, and adequate and enforced public policies and legislation

Nonetheless, participation in economic life is a necessity. People with disabilities need to earn a living and contribute to the support of their families. Economic activity is also one factor that enhances self-fulfillment and self-esteem. Work offers people with disabilities the opportunity to be recognized as contributing members of their 
communities.

Like the rest of the population in developing economies, most people with disabilities turn to self-employment because of a lack of opportunities in the job market. Although many would prefer to have a job with a regular income, self-employment is often the only option available. It is estimated that for each person with disability employed by a company in developing countries, four more generate their own income through self-employment, most of them in the informal sector. In contrast, in developed countries, less than three per cent of people with disabilities are self-employed (Harris, C. (1997).

Many people with disabilities have started shops, craft workshops and farming activities; others are involved in street vending, tailoring, carpentry, etc. In rural areas, self-employment also includes farming or agricultural activities. The majority of people with disabilities in developing countries live in rural areas, like the rest of the population. Economic inclusion programmed for people with disabilities should also give attention to rural livelihoods. Grants or loans for investment in crop production are not very common; self-help saving and lending groups are mostly used to obtain loans to buy seeds, insecticides or pesticides, to pay land rent, or to hire agricultural labor.

First and foremost, people with disabilities who opt for self-employment should have their basic needs covered prior to starting their projects. Food security, understood as guaranteed access to safe, sufficient and nutritious food, should be the first priority. According to their personal situation, people with disabilities may also need assistive devices, rehabilitation, psychological support and social inclusion programmed prior to, and/or during, their economic activity.

Successful self-employment also requires motivation, adequate personal attitude, self-confidence, and some specific know-how (education, vocational training or prior business experience) that will allow the person to successfully develop a sustainable micro or small business.

Self-employment is not the only strategy to achieve the economic inclusion of people with disabilities. For those who are not willing to take the risk of being an entrepreneur, job placement schemes and training schemes designed for employment in the formal sector may also provide some opportunities.

Some people with severe disabilities may require safety nets and social security resources to cover their special needs. The UN Standard Rules on the Equalization of Opportunities for Persons with Disabilities recognizes that "States should ensure the provision of adequate income support to persons with disabilities who... have temporarily lost or received a reduction in their income of have been denied employment opportunities"(United Nations, 1993). Unfortunately, in developing countries, this is often not the case.

4. Way Forward for Nigeria

- There should be signing into law the Persons with Disability Bill to guarantee the rights of the people living with disabilities. This law should be meant to protect them and greater protection must also be given to persons with disability to defend themselves in the society. For instance, a law that would strengthen punishment for sexual abuse against persons with disability. For another instance, a disabled person should be certified with a permanent Disability Certificate (PDC) which should make a person entitled to all the rights and privileges of a disabled person.

- Efforts should be made to improve the health status of individuals with disabilities (i.e. they should be included within mainstream health services) in order to achieve greater participation in employment and education, resulting in economic gains. Similarly, disability-specific programmes and services targeted specifically towards people with disabilities should be put in place. For instance, more investment in rehabilitation by providing more assistive devices that could greatly improve their level of functioning.

- Health facilities should be well-equipped to accommodate people with disabilities. That is, basic health centers should have not architectural barriers that prevented access for individuals with physical disabilities. Furthermore, these centers should have facilities for certain disabilities - particularly sensory or intellectual disabilities - needed for communicating of important information, such as provision of medical history, explanations of diagnoses, treatment plans and recommendations for follow-up. These facilities should be made affordable for people with disabilities who seek health services. In the same vein, discrimination and negative attitudinal behavior of by health care providers should be avoided.

- Low self-esteem and a lack of confidence can plague people with disabilities. Allowing them to have equal access to sports can enhance their gross motor skills, social and communicating abilities, as well as improve their overall health and well-being. People (children) with special needs will mature physically, socially and emotionally when participating in a recreational activity (Momyer, 2010). The list of activities include: wheelchair football, wheelchair basketball, sitting volleyball, stand-up and wheelchair tennis, table tennis, track and field, etc.

- Given the urban bias in the location of many health facilities, rural inhabitants with disabilities are particularly 
disadvantaged. As such, effort should be made to provide accessible, affordable transportation for people with disabilities who are seeking treatment.

- Exclusion from education may lead to lower employment and earning potential among people with disabilities. Not only does this make individuals and their families more vulnerable to poverty, but it can also limit national economic growth. Inclusion of people with sensory or physical impairments in schools should be encouraged and provision should be made for assistive devices. In the same vein, government organs and authorities should take into consideration the special needs and requirements of the disabled in the formulation, design of educational policies and programs. This should entail structural adaptation of all educational institutions to the needs of the disabled as much as possible.

- More effort should be made to include people with disabilities in regular or mainstream work/employment and it should be ensured that they get a job not out of pity but for what she or he could offer. The more employers are willing to hire persons with disabilities, the more other employers will follow (Wehman, 2011), thus more experience of companies that are successfully employing persons with disabilities need to be shared with larger business community (Hernandez et al., 2008). There is a need for greater collaboration between policy-makers and employers to better promote the success of disabled people in the labor market, as well as eliminating negative attitudes and prejudices and promoting employer education about the issues that disabled people face are important (Shier et al.,2009).

-Similarly, means of movement to various work places for people living with disabilities such as vehicles and elevators should be provided. Specifically, the buses and cars procured should be designed to accommodate PWDs. Likewise; toilets at work places should be designed to suit this group of persons with disabilities (Leadership, n.d.).

-Though it should not be promoted as the only option for economic inclusion, self-employment can be a good alternative, especially in a country like Nigeria where there is a general dearth of opportunities for formal sector jobs. A key requirement to successful entrepreneurship is access to credit. Microfinance institutions should extend credit and other financial services (adapt microfinance products for disabled people) to people with disabilities or low-income individuals or those barred from more formal banking institutions. In that regard, a special scheme should be designed strictly for PWDs because potential lenders frequently are reluctant to loan to people with disabilities, as they are perceived to be high risk clients: as people with disabilities also tend to be poor, they often lack collateral, guarantors or records of past repayments that are traditionally needed to satisfy more formal lending agreements. As such, these main instruments can be used to share the risk of a microfinance institution when it provides financial services to people with disabilities: financing credit lines; and guarantee funds. Financing credit lines aims to provide financial reserves for a microfinance institution to provide loans to people with disabilities. Guarantee funds are particularly useful for borrowers who do not have sufficient collateral, such as land or other assets.

Better still, specialized microfinance should be established for people with disabilities. It will be in a better position for providing people with disabilities with supporting or complementary services. Self-help groups should be established also to respond to the needs of their members and empowerment. This self-help if linked to microfinance institutions and banks may be very effective.

- Microfinance institutions should organize training for people with disabilities in order to enable them manage their businesses. In several cases, training is needed in order to learn more about the technical aspects and procedures that will ensure success. This will help close the information gap on each party's activities impeding cooperation between microfinance institutions and organizations of/for people with disabilities.

5. Conclusion

Nigeria cannot have inclusive growth unless disability is made an integral part of our growth. Considering that the economic inclusion of people with disabilities is a cross-cutting issue, successful results require complementary activities in multiple sectors. These may include health care, rehabilitation (including assistive devices), public education, barrier-free access, transport, communications, education, social welfare and community development, awareness on people with disabilities' rights, social security, sport and recreation, and adequate and enforced public policies and legislation.

In sum, persons living with disabilities should be included in the scheme of things including formal or selfemployment. A sustainable, gainful livelihood is essential for ensuring individuals with disabilities are economically empowered, can fulfill their basic needs and contribute financially to their families, communities and society at large. Without greater inclusion of people with disabilities in employment, the vicious cycle of poverty will continue to be perpetuated. 
References

Adamu, M. M. (2017).Delivering Inclusive Growth for Economic Development in Nigeria. International Journal of Entrepreneurial Development, Education and Science Research, 4(1), 209- 217.

Adeyanju, A. (2009).State and Living Conditions of Persons with Disabilities in Nigeria.https://groups.google.com/forum/\#!topic/usaafricadialogue/Bu1tPDD71VE

Ali, I. (2007). "Pro-Poor to Inclusive Growth: Asian Prescriptions". ERD Policy Brief Series No. 48, Economics and Research Department, Asian Development Bank, Manila.

Banks, L. M., and Polack, S. (n.d.). The Economic Costs of Exclusion and Gains of Inclusion People with Disabilities: Evidence from Low and Middle Income Countries. disabilitycentre.lshtm.ac.uk/.../Costs-ofExclusion-and-Gains-of-Inclusion-Report.pdf

Burns, D., and Oswald, K. (2014). 'We Can Also Make Change': Piloting Participatory Research with Persons with Disabilities and Older People in Bangladesh. Sightsavers, HelpAge International, ADD International, Alzheimer's Disease International \& Institute of Development Studies. http://www.eldis.org/go/home\&id=73080\&type=Document\#.VajmYU3bJ2M

Dell Orto, A., E., and Power, P. W. (2007). The Psychological and Social impact of Illness and Disability. 5th edition. NY: Springer Publishing Co.

DFID (2000). Disability, Poverty and Development. Department for International Development, London.

Economy Watch(n.d.). Nigeria Economic Statistics and Indicators.http://www.economywatch.com/economicstatistics/country/Nigeria/.

Elwan, A. (1999). Poverty and Disability: A Ssurvey of Literature. World Bank. 1999.

FMWASD (2011).Report of the National Baseline Survey On Persons With Disabilities (PWDs) in Nigeria.http://www.womenaffairs.gov.ng/index.php/news-updates/169-report-of-the-national-baselinesurvey-on-persons-with-disabilities-pwds-in-nigeria.

Fougeyrollas, P., Cloutier, R., Bergeron, H., Côté, J., and St Michel, G. (1999). 'Quebec Classification: disability creation process. International Network on the Disability Creation Process, Quebec.

Handicap International (2006). Good Practices for the Economic Inclusionof People with Disabilitiesin Developing Countries: Funding Mechanisms for Self-Employment.www.handicap-international.org.

Handicap International and Blindenmission, C. (2006).Making PRSP Inclusive. World Bank, Washington D.C.www.handicapinternational.de/images/pdfs_multimedia/prsp_eng_komplett.pdf .

Harris, C. (1997). 'El autoempleo de las personas con discapacidad en países en desarrollo'. IDRC Reports.

Hernandez, B., McDonald, K., Divilbiss, M., Horin, E., Velcoff, J. \& Donoso, O. (2008). Reflections from Employers on the Disabled Workforce: Focus Groups with Healthcare, Hospitality and Retail Administrators. Employee Responsibilities and Rights Journal, 20 (1), 157-164.

Heymann, J., Stein, M. A., and Moreno, G. (Eds.). (2014). Disability and Equality at Work.

New York: Oxford University Press.

Hope, T. (2003). Disabilities: Aid groups call for a UN Convention to protect rights. UNWire.

Grider, J., and Wydick, B. (2015). Wheels of Fortune: The Economic Impacts of Wheelchair Provision in Ethiopia. Journal of Development Effectiveness. Advance online publication. http://dx.doi.org/10.1080/19439342.2015.1064986

Kelikume, M. (2015).Economic Development and Growth in Nigeria.https://www.dailytrust.com.ng/news/saturdaycomments/economic-development-and-growth-in-nigeria/123963.html

Lambo, T. A. (1981). Global concern for the Disabled: Its Social and Economic Implications for

Africa. Lagos, Nigeria: Paper Delivered at the Federal Radio Corporation of Nigeria, in Honour of the International Year of Disabled Persons (IYDP). Sept. 19.

Lamicchane, K. (2015). Disability, Education and Employment in Developing Countries: From Charity to Investment. CUP.

Lamichhane, K., and Sawada, Y. (2009). "Disability and Returns to Education in a Developing Country," CIRJE FSeries CIRJE-F-645, CIRJE, Faculty of Economics, University of Tokyo.

Lanchovichina, E., and Lundstrom, S.(2009). What is Inclusive Growth. A note written for Donor

Supporting the Diagnostic Facility for Shared Growth. PRMED.

Lang, R., and Upah, L. (2008).Disability Issues in Nigeria. Commissioned by DFID. https://www.ucl.ac.uk/lcccr/downloads/scopingstudies/dfid_nigeriareport

Leadership (n.d.). Including Persons Living With Disability inthe Scheme of Things. http://leadership.ng/news/429557/including-persons-living-with-disability-in-the-scheme-of-things.

Loeb,M., and Eide,A. H.(2004).Living Conditions Among People with Activity Limitations in Malawi.Oslo: 


\section{SINTEF.}

Mauro, V., Biggeri, M., Deepak, S., and Trani, J-F. (2014). The Effectiveness of Community Based Rehabilitation Programs: An Impact Evaluation of a Quasi-Randomised Trial. Journal of Epidemiology and Community Health, 68(1), 1102-1108.http://dx.doi.org/10.1136/jech-2013-203728

McKay, A. (2008). 'Economic Growth, Inequality and PovertyReduction: Does Pro-Poor Growth Matter?', IDS in Focus, no.3.

Mendoza, R. U., and Thelen, N. (2008). 'Innovations to MakeMarkets More Inclusive for the Poor'.Development Policy Review, 26(4), 427-458.

Microsoft Encarta (2009), Dictionary.getintopc.com > Softwares > Education

Mji, G., MacLachan, M., Melling-Williams, N. and Gcaza, S. (2009) Realizing the rights of disabled people in Africa: An introduction to the special issue. Disability and Rehabilitation, 31 (1), pp.1-6.

Morgon Banks, L., and Polack, S. (2014). The Economic Costs of Exclusion and Gains of Inclusion of People with Disabilities: Evidence from Low and Middle Income Countries. CBM, International Centre for Evidence in Disability, London School of Hygiene \& Tropical Medicine. http://disabilitycentre.lshtm.ac.uk/files/2014/07/Costs-of-Exclusion-and-Gains-of-Inclusion-Report.pdf.

Momyer, A. (2010). The Importance of Sports and Recreation to Disabled Youth.http://www.livestrong.com/article/341008-the-importance-of-sports-recreation-to-disabled-youth/

NNPCgroup.com (n.d.). Nigeria Profile. nnpcgroup.com/nnpcbusiness/businessinformation/oilgasinnigeria/nigeria profile.aspx

OECD (2014). Inclusive Growth. At http://www.oecd.org.Retrieved on 25 April 2016.

President Muhammadu Buhari. 2016 budget of Change in Nigeria.

Ogujiuba, K., and Alehile, S.K. (2011).Inclusive Growth in Nigeria: Policy Issues and Options for Poverty Reduction. International Journal of Social and Economic Research, 1(1), 71-82. Available from: https://www.researchgate.net/publication/256040768_Inclusive_Growth_in_Nigeria_Policy_Issues_and_O ptions_for_Poverty_Reduction [accessed Apr 18, 2017].

Shier, M., Graham, J. R., and Jones, M. E. (2009). Barriers to Employment as Experienced by Disabled People: A Qualitative Analysis in Calgary and Regina, Canada. Disability \& Society, 24(1), 63-75.

UK Essays (2015). The Need for Inclusive Growth in India. Economic Essay. Athttps://www.ukessay.coo/ess.

Walton, E. (2012). Using literature as a strategy to promote inclusivity in high school classrooms'. Intervention in School and Clinic, 47(4), 224-33.

Wehman, P. (2011). Employment for Persons with Disabilities: Where are we now and where do we need to go? Journal of Vocational Rehabilitation, 35(1), 145-151.

World Bank (2006). Disability: Towards an Inclusive Development.http://web.worldbank.org/wbsite/external/news/news/0,,contentMDK:20264373.

WHO (2005). 'Disability, Including Prevention, Management and Rehabilitation'. Fifty-eighth World Health Assembly. www.who.int/nmh/a5817/en/.

Wolfensohn, J.D. (2003) Poor disabled and shut out. Washington Post, 3 December.

Worldatlas.com (2016). Where is Nigeria?www.worldatlas.com/af/ng/where-is-nigeria.html

World Economic Forum (2015). The Inclusive Growth and Development Report. At

www.weforum.org.

Wikipedia (2016). Economic Development. http://en.m.wikipedia.org

World Report on Disability (2011). Geneva: World Health Organization.

WRC. (2015). 'I See That It Is Possible': Building Capacity for Disability Inclusion in Gender-Based Violence Programming in Humanitarian Settings. New York: Women's Refugee Commission. https://womensrefugeecommission.org/resources/document/945-building-capacity-for-disability-inclusionin-gender-based-violence-gbv-programming-in-humanitarian-settings-overview

United Nations (1993). Standard Rules on the Equalization of Opportunities for Persons with Disabilities.United Nations General Assembly. www.un.org/esa/socdev/enable/dissre04.htm. 


\section{Appendix}

Table 1: Economic Indicator for Nigeria in 2015

\begin{tabular}{|c|c|}
\hline Indicators & Indicator Value \\
\hline GDP Growth (Constant Prices, National Currency) & $2.653 \%$ \\
\hline GDP (Current Prices, National Currency) & NGN 95,177.74 Billion. \\
\hline GDP (Current Prices, US Dollars) & US\$ 490.207 Billion \\
\hline GDP Deflator & $\begin{array}{l}136.396 \text { (Index, Base Year as per } \\
\text { country's accounts }=100)\end{array}$ \\
\hline GDP Per Capita (Constant Prices, National Currency) & NGN 390,444.92. \\
\hline GDP Per Capita (Current Prices, National Currency) & NGN 532,549.36 \\
\hline GDP Per Capita (Current Prices, US Dollars) & US\$ 2,742.86 \\
\hline GDP (PPP), US Dollars & US\$ 1,091.70 Billion \\
\hline GDP Per Capita (PPP), US Dollars & US\$ 6,108.41 \\
\hline GDP Share of World Total (PPP) & $0.962 \%$ \\
\hline Implied PPP Conversion Rate & 87.183 \\
\hline Investment (\% of GDP) & $14.48 \%$ \\
\hline Gross National Savings (\% of GDP) & $12.049 \%$ \\
\hline Inflation, Average Consumer Prices (Indexed to Year 2000) & $173.125($ Index, Base Year $2000=100)$ \\
\hline Inflation (Average Consumer Price Change \%) & $9.01 \%$ \\
\hline Inflation, End of Year (Indexed to Year 2000) & $180.15($ Index, Base Year $2000=100)$ \\
\hline Inflation (End of Year Change \%) & $9.554 \%$ \\
\hline $\begin{array}{l}\text { Import Volume of All Items Including Goods and Services (Percent } \\
\text { Change) }\end{array}$ & $-1.853 \%$ \\
\hline Import Volumes of Goods Only (Percent Change) & $12.369 \%$ \\
\hline $\begin{array}{l}\text { Export Volume of All Items Including Goods and Services (Percent } \\
\text { Change) }\end{array}$ & $11.354 \%$ \\
\hline Export Volumes of Goods Only (Percent Change) & $9.698 \%$ \\
\hline Unemployment Rate (\% of Labour Force) & $9.9 \%$ \\
\hline Population & 178.721 Million \\
\hline General government revenue (National Currency) & NGN 7,445.45 Billions. \\
\hline General government revenue (\% of GDP) & $7.823 \%$ \\
\hline General government total expenditure (National Currency) & NGN 11,236.69 Billions. \\
\hline General government total expenditure (\% of GDP) & $11.806 \%$ \\
\hline Total Government Net Lending/ Borrowing (National Currency) & NGN -3,791.24 Billions. \\
\hline Total Government Net Lending/ Borrowing (\% of GDP) & $-3.983 \%$ \\
\hline Fiscal Year Gross Domestic Product, Current Prices & NGN 95,177.74 Billions. \\
\hline Current Account Balance (US Dollars) & US\$ -11.918 Billion \\
\hline Current Account Balance (\% GDP) & $-2.431 \%$ \\
\hline
\end{tabular}

Source: Economy Watch (n.d.). 


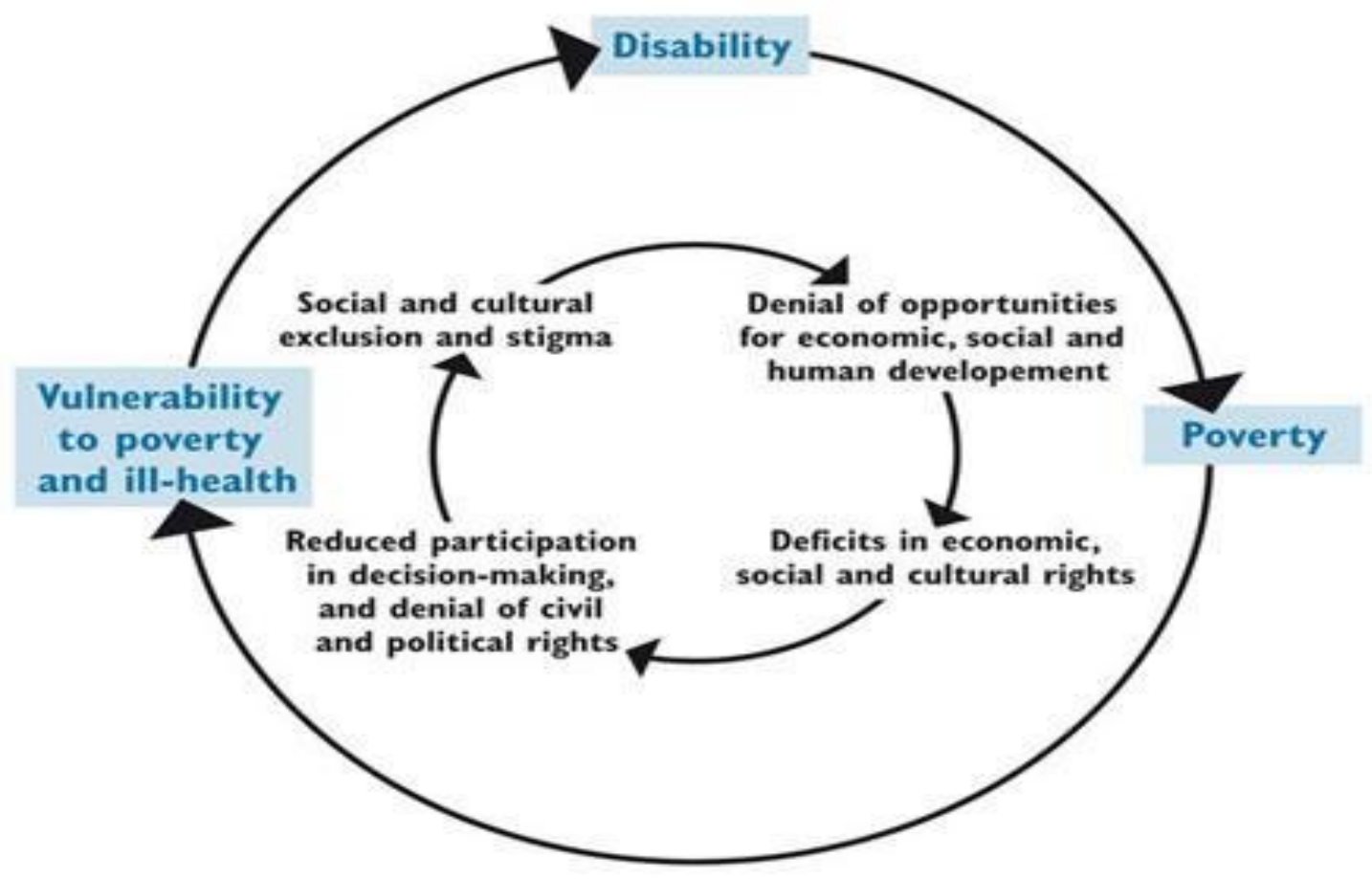

Figure 1:The vicious circle between poverty and disability

Source: Banks and Polack (n.d.).

\section{Copyrights}

Copyright for this article is retained by the author(s), with first publication rights granted to the journal.

This is an open-access article distributed under the terms and conditions of the Creative Commons Attribution license (http://creativecommons.org/licenses/by/4.0/) 